Article

\title{
When Institutions Collide: The Competing Forces of Hospitals Sponsored by the Roman Catholic Church
}

\author{
Kenneth R. White \\ Department of Health Administration, Virginia Commonwealth University, P.O. Box 980203, \\ Richmond, VA 23298-0203, USA; E-Mail: krwhite@vcu.edu; Tel.: +1-804-828-8651; \\ Fax: +1-804-828-1894
}

Received: 29 October 2012; in revised form: 13 December 2012 / Accepted: 17 December 2012 / Published: 21 December 2012

\begin{abstract}
For centuries, the Catholic Church has been a major social actor in the provision of health services, particularly health care delivered in hospitals. Through a confluence of powerful environmental forces at the beginning of the twenty-first century, the future of Catholic health care is threatened. Although United States Catholic hospitals are a separate case of private, nonprofit hospitals, they have experienced environmental pressures to compete with other hospital ownership types and, on some dimensions, Catholic hospitals are indistinguishable from other hospitals. This article conceptualizes United States Catholic hospitals as having competing institutional forces that are not always compatible. To keep pace with the changing demands of religion and the social role of the hospital, Catholic hospitals continue to redefine themselves. An adaptive framework is used to explain choices Catholic hospitals may need to make to justify their existence.
\end{abstract}

Keywords: Catholic hospitals; institutional theory; Catholic identity

\section{Introduction}

For centuries, the Roman Catholic Church has been a major social actor in the provision of health services, particularly health care delivered in hospitals. Catholic-sponsored hospitals are a special case of organizations in the health care sector, with two strong institutional environments defining their identity. Not only are these hospitals subjected to the institutional and technical environments that all contemporary hospitals face [1], but they also have the added institutional environment of the Roman Catholic Church. These institutional forces have interacted to form organizations that find it increasingly difficult to satisfy the opposing sources of demands on how the organization should perform. 
Hospitals are important in the study of organizations. As complex organizations, hospitals provide fertile ground for study due to their wide variety of structures, missions, and ownership types. A great deal of research applying organizational theory has been conducted to explain the existence and structure of health care organizations [2], and as hospitals evolve and adapt to environmental forces, more knowledge is needed on the unique contribution of hospitals with varying ownership and control. Hospitals sponsored by the Roman Catholic Church are good examples of organizations that contend with environmental forces that may be unlike other hospital ownership types, as this paper will describe.

The purpose of this paper is to examine the collision of the demands on organizational activity that differing environments of the Roman Catholic Church and the contemporary hospital dictate. Powerful forces deriving from the Roman Catholic Church are pressuring Catholic hospitals to retain their distinctive mission of providing a church-sponsored ministry, while at the same time pressures from the hospital environment promote secular uniformity in order to survive in a competitive marketplace. This paper analyzes assumptions of the institutional perspective of organizational study as they relate to organizations in multiple organizational fields, and various structural scenarios available to them. Finally, organizational implications are presented, as well as a discussion about research that describes the ways that Catholic hospitals have adapted to environmental pressures.

\section{Background}

The earliest Catholic hospitals were founded in the mid-nineteenth century to respond to epidemics and the unprecedented growth of European immigrants and the social problems inherent with rapid urban growth ([3], p. 18). During this period, there was strong anti-Catholic hostility from protestant Americans. Many Catholic hospitals were located in densely populated urban areas to provide charitable services to Catholics who lived in their parishes, although non-Catholics were readily accepted as patients, also [4]. Catholics formed strong attachments to their own Catholic hospitals ([3], p. 19). As society has become increasingly more secularized, the link between churches and their sponsored social institutions, like hospitals, has weakened [5]. Catholic hospitals have shifted from "ecclesiastical" institutions in the early part of the twentieth century to become the largest North American private, nonprofit sector effort delivering medical care, long-term care, and related health services to persons in need. Over time, the ecclesiastical presence has been eroded as the workforce in Catholic health care has shifted from predominantly Catholic and members of religious institutes to one that is more secular. Concomitantly, Catholic health care organizations have responded to market and regulatory pressures by changing their scope of services, organizational arrangements, and financing mechanisms [6,7]. A challenge central to Catholic identity has been maintaining fidelity to religious values of providing comprehensive health care to vulnerable and underserved populations.

With declining numbers of Catholic religious orders and an increasingly more secularized society contributing to changes in the Catholic health care tradition over time, and added market and regulatory pressures on all hospitals, it has been difficult to maintain a unique niche for Catholic hospitals. Yet, as Catholic hospitals struggle to keep pace with economic, political and legal pressures, while surviving as fiscally sound organizations, they continue to be faced with pressures from the Roman Catholic Church to maintain a distinctive Catholic identity [8-15]. 


\section{Elements of Catholic Identity}

Catholic health care has a few notable differences from health care controlled by other health care delivery systems [14-17]. The Code of Canon Law for the Roman Catholic Church grants the diocesan bishop the ability to determine the qualities necessary to identify an institution as Catholic, and thus, as sharing in the mission of the Church. The moral responsibility of Catholic health care is outlined in the Ethical and Religious Directives for Catholic Health Care Services. The Directives describe medical procedures that are judged morally acceptable by the United States Conference of Catholic Bishops. A section was added in 1994 (and modified in 2001 and 2009) that deals with new partnerships between Catholic and non-Catholic organizations and providers. Specifically, “ . . . [T]he purpose of the Directives is twofold: first, to reaffirm the ethical standards of behavior in health care that flow from the Church's teaching about the dignity of the human person; second, to provide authoritative guidance on certain moral issues that face Catholic health care today” ([18], p. 4).

A revision of the Directives in 2009 was prompted by concern from the Vatican that church rules were being misapplied in some partnerships where the Catholic partner was not sufficiently distanced from the provision of services prohibited by the Church. The latest edition of the Directives maintains the language in the 2001 version reminding Catholic partners that they "should avoid entering into partnerships that would involve them in cooperation with the wrongdoing of other providers," with an implicit Directive: "Catholic health care organizations are not permitted to engage in immediate material cooperation in actions that are intrinsically immoral, such as abortion, euthanasia, assisted suicide, and direct sterilization” ([18], p. 37). The revisions appear to have stricter interpretation of partnership arrangements, which may slow down or end discussions of arrangements with potential nonprofit partners. In order to have the ability to respond quicker to changes in the environment, some Catholic systems may restructure their organizations and drop formal ties with the Roman Catholic Church in order to remove barriers to expansion [19].

Theologians have described Catholic identity as it is applied to the delivery of health care services $[6,9,20]$. Common themes that emerge in describing Catholic identity are the ways the values of the Roman Catholic Church are combined, focused, and emphasized in the health care ministry [21]; the responsibility to community, human dignity and the call to justice [22]; and the preferential service to the poor. Catholic identity may be realized in the provision of certain services that reach marginalized populations which tend to be underserved or altogether neglected by public and for-profit health care systems (e.g., services that may be "stigmatized" such as HIV/AIDS, chemical dependency, psychiatric, epilepsy) or services that promote the sanctity of life (e.g., perinatal services) and the dignity of death (end-of-life services such as palliative care units, hospice, pain management). Conversely, being "Catholic" also involves not providing other services, such as sterilization procedures [23], physician-assisted suicide, or certain counseling services that promote elective abortions.

Empirical analyses of Catholic hospitals compared to secular ownership types have shown that there are similarities on certain dimensions like financial performance and other operational performance indicators [12,24-30]. However, in characterizing Catholic identity as the provision of certain mission-driven services that enhance fidelity to social justice and compassionate care, White and Begun $[28,29]$ have shown that there were certain differences between Catholic and non-Catholic hospitals. Catholic hospitals have differentiated themselves on the provision of certain services [31,32], 
although community need and financial determinants may be stronger predictors of services [33]. For example, hospitals located in poorer communities are meeting the basic health care needs first and they may not have the excess capital to invest in additional services to improve access to care.

\section{The Institutional Perspective of Catholic Hospitals}

Catholic hospitals may be viewed from an open systems perspective [34,35]. In this way, one may depict Catholic hospitals as organizations responding and adapting to environmental forces, including, but not limited to, institutional pressures as predicted by the institutional theory perspective.

Institutional theory considers the organization as an adaptive organism responding to the characteristics and commitments of participants as well as to influences from the external environment [36]. This focus on the sociological aspects of organizations makes institutional theory useful for analyzing Catholic hospitals, as "institutions" heavily imbued with values, rituals, myths, and ceremonies emanating from the tradition of the Roman Catholic Church and its sponsoring religious communities (orders of religious men or women). As explained by Scott and Meyer ([37], p. 2), ". . . Hospital structures reflect standard forms created in the wider environment: The existence of such organizations depends in good part on the environmental institutionalization of such forms."

Institutional theory is particularly relevant for the study of Catholic hospitals, for several reasons:

(1) Because the ownership and control of Catholic health care is by the Roman Catholic Church, the institutional component of Catholic hospitals is strong;

(2) Hospitals face pressures for efficiency and effectiveness, and are required to exist in strong technical environments; and

(3) Sociological forces that shape organizations, such as values, traditions, and rituals are considered. The institutional perspective considers the way an organization's culture explains its existence.

\subsection{Technical and Institutional Environments}

Examining the technical and institutional components in an environment helps define what, in fact, an organization and systems of organizations are [38]. Organizational researchers [39] assert that it is important to distinguish organizations based on their degree of technical and institutional environments. Technical environments are those in which organizations produce a product or service that is exchanged in a market such that organizations are rewarded for effective and efficient performance. Institutional environments are characterized by the elaboration of rules and requirements to which individual organizations must conform in order to receive legitimacy and support. Institutional environments reward organizations that have correct structure and processes; technical environments reward organizations that achieve correct outcomes.

Several constructs of institutional theory are useful in the analysis of Catholic health care organizations. Isomorphism, or the tendency to become similar to other organizations that experience like environmental and institutional environments, is a central construct of the institutional perspective [40]. Other tenets of this theoretical perspective include deeply held beliefs and values of organizations, boundary spanning activities, and the process of gaining legitimacy. 


\subsection{Isomorphism}

Isomorphism is the notion that an organization will imitate other organizations in its environment where the same set of environmental pressures exists. Organizations not only compete for market position and specialized niches, but also for political power and institutional legitimacy, and for social as well as economic fitness. The evolution of hospitals evidences this point: while at one time hospitals were charitable organizations for the sick and injured, they have become more businesslike with for-profit and nonprofit hospitals exhibiting similar attributes, and espousing similar missions and goals [41-44]. There has been a concomitant adoption of corporate management and governance structures [45].

DiMaggio and Powell [40] described three mechanisms through which institutional isomorphic changes occur: (1) coercive isomorphism that stems from political influence and regulatory pressures; (2) mimetic isomorphism resulting from standard responses to uncertainty; and (3) normative isomorphism, associated with professionalization, or the formal educational process and the growth of networks across organizational boundaries. Organizations tend to model themselves after similar organizations in their field that they perceive to be more legitimate or successful. Abrahamson and Rosenkopf [46] have used the term "institutional bandwagons" to describe the pressures of organizations to adopt an innovation, not because of their individual assessments of the innovation, but because of the sheer number of organizations that have already adopted the innovation. All three forms of isomorphism of isomorphism are applied to Catholic hospitals.

\subsection{Beliefs and Values}

Important in the study of Catholic hospitals is the construct of beliefs and values that sustain the legitimacy of institutions. Institutional theorists have described these beliefs and values as "rationalized myths." They are rational in the sense that they are represented in elaborated systems of laws, professional standards, and licensure or accreditation requirements that are adopted as a way to accomplish an organization's objectives. They are myths in the sense that they are supported by widely held beliefs that cannot be tested. Institutional theorists purport that survival depends on conformity to rationalized myths [42,47-49].

Throughout the history of Catholic hospitals, there have been redefinitions of its identity to keep pace with the changing context of society, religion, and health care sponsorship [4]. A primary institutional identity that began two hundred years ago as a social welfare ministry in response to urban need and Christian charity is now under pressure to define itself increasingly by its technical capacity. To maintain its connection to the Church, and to respond to technical pressures of modern hospitals, a special case of private, nonprofit health care institutional providers has emerged.

\subsection{Boundary Spanning Activities}

The way that Catholic hospitals organize for responding to the external environment and the various stakeholders is through boundary spanning. There are three forms of boundary spanning activities. First, boundary redefinition occurs when a hospital joins another organization or organizations that increase the organizational boundary. This is what happened when individual Catholic hospitals 
organized as systems of hospitals in the latter part of the twentieth century, with increasing corporatization of their organizational structures and processes [47]. In addition, for Catholic hospitals, becoming members of multi-hospital systems may have started the trend to partner with hospitals in different locations as well as different religious community sponsors. The trend has continued for Catholic hospital partnerships with health systems that are not solely comprised of Catholic hospitals.

Second, buffering is a boundary spanning activity that serves to protect an organization against disturbing environmental influences. For example, buffering may involve augmenting or centralizing administrative structures in order to "protect" the technical core. Catholic health systems have developed centralized offices of corporate compliance in response to pressures for more accountability in organizational ethics. To bolster this activity, The Catholic Health Association of the USA provides guidance and direction to its member hospitals on policy development and educational programs for corporate compliance.

Third, bridging is a boundary spanning activity that serves to connect organizations to other organizations. Bridging strategies involve creating linkages to other organizations through shared services and other product exchange opportunities [50]. As hospitals have merged or other partnership arrangements have been formed, more opportunities have existed for bridging [6]. Organizational structures may not involve changes in legal definitions but may involve partnership agreements for purchasing, negotiating with managed care companies, networking, and developing strategic health alliances [51]. For example, a statewide network of Catholic hospitals may have an agreement to provide certain services, equipment, or plans for emergencies.

The three boundary spanning mechanisms-boundary redefinition, buffering, and bridging — serve to extend the institution into its environment. This contributes to isomorphism, or becoming homogeneous with other types of hospital ownership and control [50].

\subsection{Legitimacy}

Institutional legitimacy is the essence of survival of hospitals sponsored by the Catholic Church. Although the legitimacy construct has been associated with institutional theory, Suchman [52] pointed out that few have defined it. Moreover, there are contradictory uses of the term. In the strategic tradition, legitimacy is referred to as the way organizations use symbols to gain the support of society. The institutional school (for example, [38,40,53-55]) "adopts a more detached stance and emphasizes the ways in which sector-wide structuration dynamics generate cultural pressures that transcend any single organization's purposive control" ([52], p. 572). In other words, legitimacy refers to the way the organizational culture explains an organization's existence [39,52]. This paper is concerned with the aspect of legitimacy that derives from the distinct contribution of Catholic hospitals, since that is necessary in order to justify a distinct ownership type.

\section{Competing Environmental Forces}

The environments of the Roman Catholic Church and the contemporary hospital are often contradictory. Figure 1 describes selected environmental forces that are impinging on Catholic hospital identity, as explained below. 


\subsection{Roman Catholic Church Environment}

The Roman Catholic Church environmental forces are elaborate theological structures, processes, and directives emanating from a highly centralized body, the Vatican. Cardinals, archbishops, or bishops, interpret the policies of the Church for the local Catholic hospitals in their jurisdictions. In addition, the sponsoring religious institutions, such as orders of nuns or brothers, impose their particular charism, or particular sacred mission, on the individual hospital. This layer of Church hierarchy provides a strong institutional environment that is unknown to secular hospitals.

Although the link to Catholic doctrine and the belief that health care is a right has remained central to Catholic identity, other environmental forces outside the control of the Catholic Church have affected Catholic hospital identity. The increasing secularization of society, the decreasing numbers of religious (nuns, priests, and others) who are leaders and providers of Catholic health care services, and the decreasing reliance on the Church to support its sponsored social works, are forces that are reshaping the identity of Catholic hospitals.

However, because of the strong Catholic institutional environment, the pressure is strong to perpetuate a Catholic health care ministry. Therefore, debates about Catholic identity from the Church's perspective are centered on adherence to Church doctrine that require the provision of certain services in certain ways, while prohibiting others.

\subsection{Secular Hospital Marketplace Environment}

The contemporary hospital has become a complicated amalgam of business structures and elaborate processes for delivering medical care, no longer dependent on philanthropy and church-donated labor (in the form of free services from priests, nuns, and others) for financial viability. The rise of technology, new inventions, and discoveries that aid in the diagnosis and treatment of diseases are central to the environment that has shaped the contemporary hospital. Furthermore, with the advent of federal and state programs to finance health care for the poor and elderly in the 1960s, philanthropy began to decrease. The often-opposing forces of increased regulation and market competition posed new environmental constraints on hospitals. Increased competition for lower cost and higher quality health care services was being demanded. Payers, employers, and policymakers wanted lower costs and higher quality, or, at least more value for resources expended. The emergence of for-profit corporations into the market in the 1970s added an additional burden with the increase in the provision of uncompensated, unpopular, or stigmatized, care in nonprofit settings [56].

What have emerged in the twenty-first century are hospitals with a strong institutional environment and a strong technical environment. Like the strong institutional environment of the Roman Catholic Church, the hospital has elaborate administrative structures and bureaucracies. However, the hospital institutional environment has become more coupled to the technical environment due to the demands for increased quality and safety, decreased cost, and compliance to the standards of regulatory bodies such as The Joint Commission, Centers for Medicare and Medicaid Services, National Committee on Quality Assurance, and others. Catholic hospitals - a separate classification of nonprofit hospitals in the United States-must be equal to other hospitals with which they must compete for scarce resources [6]. 


\section{The Clash of Catholic Church and Hospital Marketplace Environments}

The collision course of the competing Catholic Church and hospital technical environments is played out in the definition of Catholic identity. As shown in Figure 1, Catholic hospital identity is defined by the various mission-driven constructs that are central to the sponsoring organization, within the context of Catholic doctrine. Ways that hospitals characterize their identity are to describe a commitment to social justice, effective and efficient stewardship of resources, the provision of compassionate care, and the treatment of all persons with dignity and respect.

Figure 1. The Impact of Catholic Church and Hospital Environments on Catholic Hospital Identity.

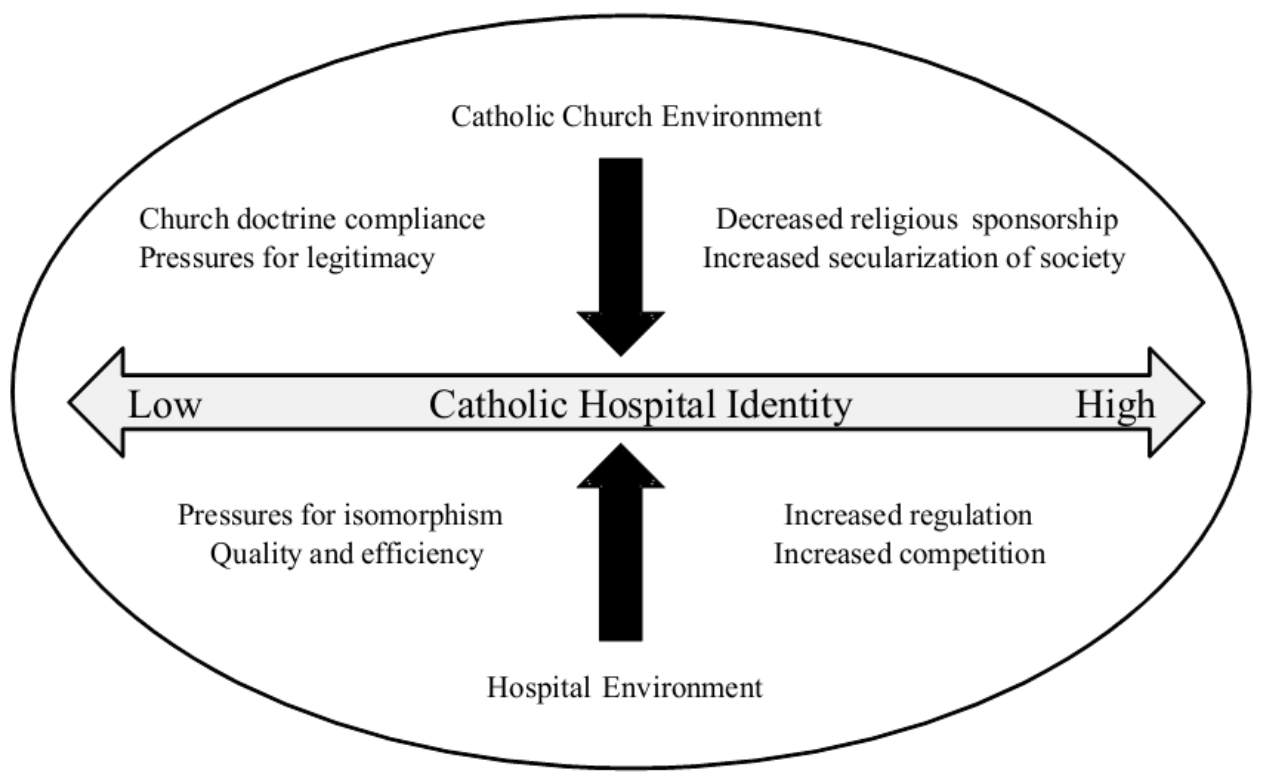

While the institutional environment of the Church wants to maintain legitimacy by being able to describe a distinctive contribution to its health care ministry, the Church identity has become increasingly harder to define and maintain. Links to the Roman Catholic Church are fewer. The numbers of health care executives who are members of religious orders are decreasing, thus, reliance on lay persons to carry out the sacramental nature of the ministry [20] has placed additional threats to Catholic identity. The once-prominent religious icons and symbols are not as prevalent in Catholic hospitals as they had been in earlier hospitals.

The environmental pressures of the Roman Catholic Church and the modern hospital are summarized here. The strong institutional pressures of the Catholic Church are:

1. To maintain legitimacy of Catholic sponsorship of hospitals and the adherence to Church doctrine;

2. To infuse Catholic identity into hospitals that are increasingly being led by laity;

3. To promulgate the beliefs and values of the Roman Catholic Church through a sponsored social ministry that a more secular society may not appreciate; and

To retain sponsorship of Catholic health care organizations, as an extension of the healing ministry of Jesus Christ.

The strong technical pressures of hospitals are:

1. To compete in a market-based economy (isomorphic pressures);

2. To maintain legitimacy through regulatory body compliance and approval; 
3. To provide high quality, low cost health care services with acceptable outcomes; and

4. To improve health status of the communities being served and to satisfy the needs of all stakeholders (boundary spanning).

Together, the aforementioned institutional and technical pressures represent a collision course of competing, and often contradictory, environments for shaping the contemporary hospital. Conflicting institutional demands may lead to organizational paralysis or breakup [57]. The way that Catholic hospitals may respond to this phenomenon is described in the next section.

\section{Organizational Responses to Environmental Pressures}

With strong institutional and technical environments in which to enact Catholic health care, organizations respond in their self-interest in different ways. This is akin to saying that Catholic hospitals have a strategy in order to survive [17]. Strategic adaptation to environmental pressures may be described as a continuum from low to high adaptation. The adaptation response may yield organizations that are very different from the traditional Catholic, acute care hospital.

If one considers the institutional pressure for Catholic identity and the technical pressure for efficiency and effectiveness as dichotomous dimensions, then a fourfold grid describes hypothetical organizational responses to environmental adaptation, as exhibited in Figure 2.

Figure 2. Adaptive Framework.

\begin{tabular}{|c|c|c|c|}
\hline \multicolumn{4}{|c|}{ Catholic Institutional Pressure Adaptation } \\
\hline \multirow{3}{*}{ 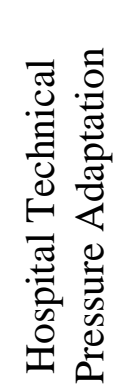 } & & High & Low \\
\hline & $\stackrel{\widetilde{T}}{.00}$ & Acute care; rationalized myth & Acute care; ownership conversion \\
\hline & 芆 & $\begin{array}{l}\text { Change in business to Catholic } \\
\text { sponsored assisted living, long } \\
\text { term care, or other business }\end{array}$ & $\begin{array}{l}\text { Closure, sale, or changed line of } \\
\text { business }\end{array}$ \\
\hline
\end{tabular}

High technical, high institutional. In this scenario, the acute care hospital is likely to survive, although it will be increasingly harder to detect differences between Catholic and secular hospitals. If hospitals do maintain a distinctly Catholic mission, it will be because the deeply held beliefs and values and theological assumptions are integrated into the technical core.

High technical, low institutional. Here the acute care hospital does not adapt to the strong institutional environment of the Catholic Church, although technical adaptation is high. This organization has legitimacy as a hospital without the Catholic identity. In this case, an ownership conversion is likely to occur.

Low technical, high institutional. This organizational response is the Catholic hospital of yesteryear. With low technical pressures, it is not likely that an acute care hospital would survive because consumers and payers demand efficiency and quality. So, a Catholic hospital would likely transition from an acute care hospital to a new organizational form. It may or may not be related to health care. In this scenario, Catholic identity is the prevailing strategic influence, thus meeting the needs of the 
community through a sponsored social ministry that could involve housing, assisted living, long term care services, or other types of business.

Low technical, low institutional. This organizational response represents a shift from acute care and Catholic identity that could result in closure, sale, or changing the line of business. It would cease to exist as a Catholic organization because it would not be in compliance with the rational processes that define Catholic organizations (such as the Religious Directives and determinations by local bishops). It would cease to be a hospital because it would not conform to the high technical pressures required.

\section{Catholic Hospitals Respond}

The survival of Catholic hospitals qua Catholic hospitals depends on their ability to maintain legitimacy as a sponsored-work of the Roman Catholic Church, while, at the same time, competing with secular hospitals in a market-based economy. Survival may involve a redefinition of what it means to be a Catholic hospital, a transition from sponsoring acute care services to providing other health care or social ministries beneficial to their communities and consistent with Church doctrine, or the abandonment of Catholic identity entirely. What actually is happening is a combination of the scenarios presented in the previous section because the technical pressures are highly variable across the United States. For example, some states have stronger technical environments than others, e.g., California and Arizona as opposed to Arkansas or Mississippi. It is predicted that Catholic hospital identity would be stronger in states with lessened regulatory constraints on the technical aspects of health services delivery.

As exhibited in Figure 3, Catholic hospitals have adapted to Church and hospital environments in various ways. For heuristic presentation, the typology is simplified in Figure 3 (in reality the typology variables are continuous, not discrete as shown). The following sections describe ways that Catholic hospitals have adapted to the mixed nature of technical and institutional environments.

Figure 3. Adaptation of Catholic Hospitals.

Catholic Institutional Pressure Adaptation

High

Low

\begin{tabular}{|c|c|c|c|}
\hline . & 昫 & $\begin{array}{l}\text { Mastering Ministry and } \\
\text { Maximizing Margin } \\
\text { (Church and hospital) }\end{array}$ & $\begin{array}{l}\text { Changing Identities } \\
\text { (From Church to } \\
\text { secular) }\end{array}$ \\
\hline 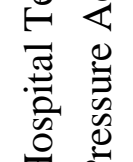 & 䇥 & $\begin{array}{l}\text { Modifying Missions } \\
\text { (From acute care to } \\
\text { other social ministry) }\end{array}$ & $\begin{array}{l}\text { Acquiescing Assets and } \\
\text { Identity } \\
\text { (Closure or sale) }\end{array}$ \\
\hline
\end{tabular}

\subsection{Mastering Ministry and Maximizing Margin}

Catholic hospitals that provide acute care services are adapting to high institutional and high technical environments by mastery of mission and margin, simultaneously. That is, pressure for efficiency, market share, and quality in the technical environment is one master. Another master is the 
pressure to provide the technical services in a manner that is consistent with and supportive of Church doctrine. This has created isomorphism and differentiation with secular hospitals on several dimensions.

Catholic hospitals have been shown to be similar to other hospital ownership types on certain dimensions. To date, organizational research has concentrated on ownership and performance, in terms of financial outcomes, efficiency, and returns to the community. Catholic hospitals have been shown to perform similarly to their secular counterparts as measured by return on assets, operating expense per discharge, and profit margin [25,26]. Another dimension of isomorphism comes from normative sources. With the decline in the numbers of Catholic hospital-sponsored schools of nursing and other training programs and the concomitant decrease in religious men and women who transmitted Catholic values and normative processes, clinical providers are educated in secular colleges and universities. This has yielded nurses and other providers that may not have a uniquely Catholic perspective on providing health care [58].

Organizational differences exist in other areas involving service provision as it stems from missiondriven values that attempt to define Catholic identity. A commitment to social justice is carried out in the provision of health care to poor and marginalized populations. For instance, provision of charity care and certain socially stigmatized services (for example those for HIV/AIDS, mental health and substance abuse) are ways to operationally apply Catholic identity. Research has been conducted comparing provision of charity care and certain services by various ownership types of hospitals. Results suggest that Catholic hospitals may be differentiated from other private, nonprofit hospitals on these dimensions and would likely be differentiated from investor-owned hospitals [26,28-30,56,59]. However, in the United States these studies suggested that Catholic hospitals are second to large, public teaching hospitals in the provision of charity care and socially stigmatized services.

There are certain areas where Catholic hospitals continue to differentiate themselves as distinctly Catholic. From the strong Catholic tradition of respect for life and the dignity of death, services that involve procreation and palliation are empirically different when comparing Catholic and secular hospitals. Catholic hospitals tend to provide more access to obstetric and pediatric services [26] while restricting services resulting in abortion and reproductive sterilization [23]. At the other end of the life spectrum, Catholic hospitals emerged as leaders in the provision of palliative care, pain management, and other end-of-life services [31].

For Catholic hospitals to continue serving the strong institutional masters of Church and hospital, several demands must be satisfied [60]. First, they must continue to generate enough revenue over costs to fund charity care and form community outreach at levels that are higher than their secular counterparts. Second, the religious orders or diocesan sponsors that originally established them must find ways to inculcate a distinct way to carry out the Catholic mission in the new lay leadership better than they have in the past [61-63]. In sum, the canonical responsibility of stewardship, or the oversight of a ministry's effectiveness in light of its purpose and mission, must maintain and ensure an authentic identity of the Catholic health care ministry. The point of stewardship is to keep the essence of the mission at the forefront of deliberations, planning decisions, strategic considerations, and staff training within the organization [64], and to provide services that are reflective of organizational values [33]. 


\subsection{Changing Identities}

The pressure to serve two masters (that is, Catholic Church and hospital) may be too great, resulting in a sacrifice of the Catholic identity. Pressures to continue providing hospital services override the requirements to remain Catholic. Such is the case with mergers, acquisitions, or other ownership conversions. The hospital remains viable, although the official Catholic identity is jettisoned. This has been seen in the declining numbers of Catholic hospitals from 640 in 1990 to 629 in 2010 [65] and the consolidation of most of those hospitals into 56 Catholic health care systems [66].

In the face of healthcare reform and increasing business demands to compete and respond nimbly to market pressures, some system ownership conversions have occurred in order to separate from the Catholic Church $[19,67]$. When system leaders believe that changed names and governance structures of the newer non-Catholic entities will make it easier to work with non-Catholic partners without being required to adhere to the Ethical and Religious Directives and submission to the local bishops, redefining ownership may be necessary to satisfy the health care needs and demands of the communities being served.

\subsection{Modifying Missions}

The pressure to imitate may reduce the level of organizational innovation and creativity [68]. This, in turn, may lead to a hospital that may not be able to compete in a rapidly changing environment or one where innovation is crucial. To maintain fidelity to a Catholic sacramental perspective [60], the organization may transition from providing acute care services to providing transitional, continuing retirement care, or ministry other than acute care hospital services. This has been witnessed by health systems becoming more involved in providing housing options for the poor, hospice care for the dying, residential services for the socially stigmatized (such as homes for those dying with AIDS), clinics in immigrant labor camps, addiction treatment centers, or outpatient mental health centers.

\subsection{Acquiescing Assets and Identity}

In some cases where the institutional and technical pressures are too great, Catholic hospitals have been unable to survive as hospitals or as distinctly Catholic organizations. This has resulted in closures or acquiescence of Catholic hospital assets and identity [69]. If closed, a community would lose access to health care services. If sold, the new organization would face a different institutional environment determining whether the organization would continue to be a hospital.

\section{Conclusions}

Based on institutional theory, Catholic health care will continue to redefine itself, as the environment continues to change. In this way, traditions and rituals will take on new meanings. Promulgating rationalized myths will be even more important with the increasing secularization of society and the concomitant decrease in the use of religious icons and symbols, and the decline in the numbers of religious sponsors.

Institutional theory predicts that hospital ownership types, in their provision of services, will exhibit isomorphism (coercive, mimetic, and normative) to the extent that they share similar environments. 
However, organizations may face pressures for isomorphism from different organizational fields that are contradictory. Such is the case of Catholic hospitals. Powerful forces deriving from the Roman Catholic Church are pressuring Catholic hospitals to retain their distinctiveness, while simultaneously, pressures for isomorphism are derived from environmental forces in the hospital industry [6,26]. Institutional theorists have tended to assume that pressures for isomorphism affecting the organizational field are uniform across members of the field. In the case of hospitals with different ownership types, this is not true. Ownership type creates isomorphic pressures of its own, for uniformity within the ownership type. To maintain fidelity to the sacramental meaning of the Church, options other than acute hospital care should be investigated or corporate structures need to be redesigned to separate from the Catholic Church. A refined institutional theory should recognize the membership of organizations in multiple organizational fields, with pressures that may be conflicting.

\section{Acknowledgements}

This article is adapted with permission of John Wiley \& Sons, Inc. from Kenneth R. White. "When Institutions Collide: Hospitals Sponsored by the Roman Catholic Church.” In Advances in Health Care Organization Theory, edited by Stephen S Mick; Mindy E Wyttenbach. San Francisco: Jossey-Bass, 2003, pp. 79-98.

\section{References}

1. Anne Somers. Hospital Regulation: The Dilemma of Public Policy. Princeton: Princeton University Press, 1969.

2. Stephen S. Mick, ed. Innovations in Health Care Delivery: Insights for Organization Theory. San Francisco: Jossey-Bass, 1990.

3. Barbra Mann Wall. Unlikely Entrepreneurs: Catholic Sisters and the Hospital Marketplace, 18651925. Columbus: The Ohio State University Press, 2005.

4. Suzy Farren. A Call to Care: The Women Who Built Catholic Healthcare in America. St. Louis: The Catholic Health Association, 1996.

5. Edward Patrick Freeland. "The Dynamics of Nonprofit and Public Organizational Growth in Health Care and Higher Education: A Study of U.S. States.” PhD diss., Princeton University, 1992.

6. Kenneth R. White. "Hospitals Sponsored by the Roman Catholic Church: Separate, Equal, and Distinct?” Milbank Quarterly 78 (2000): 213-239.

7. Barbra Mann Wall. American Catholic Hospitals: A Century of Changing Markets and Missions. New Brunswick: Rutgers University Press, 2011.

8. Catholic Health Association. "Mission-Driven Market Strategies: Lessons from the Field.” Health Progress 79 (1998): 50-53.

9. Clarke E. Cochran. "Keeping Hospitals Catholic.” Commonweal (2000): 12-16.

10. J. Bryan Hehir. “Identity and Institutions.” Health Progress 76 (1995): 17-23.

11. C. J. Kauffman. "The Modern Association: Preserving a Catholic Presence in the U.S. Healthcare System.” Health Progress 71 (1990): 35-46. 
12. Thomas R. Prince. "Assessing Catholic Community Hospitals Versus Nonprofit Community Hospitals, 1989-1992.” Health Care Management Review 19 (1994): 25-37.

13. Ursula Stepsis, and Dolores Liptak. Pioneer Healers: The History of Women Religious in American Health Care. New York: Crossroad, 1989.

14. J. M. Sullivan. “An Opportunity for Positive Change: We Have the History, Experience, and Will to Preserve a Catholic Presence in Healthcare.” Health Progress 7 (1993): 56-65.

15. Neal McLaughlin. “Shaky Outlook.” Modern Healthcare 42 (2012): 25.

16. Judy Cassidy. "Catholic Identity is Based on Flexible, Reasonable Tradition.” Health Progress 75 (1994): 16-17, 25.

17. Thomas H. Vowell. "Preserving Catholic Identity In Mergers: An Ethical and Canon Law Perspective.” Health Progress 73 (1992): 28-33.

18. United States Conference of Catholic Bishops. Ethical and Religious Directives for Catholic Health Care Services, $5^{\text {th }}$ ed. Washington: USCCB Publishing, 2009, p. 4.

19. A. Selvam. "Business Conversion.” Modern Healthcare 42 (2012): 6-7, 14-15.

20. Clarke E. Cochran. "The Common Good and Healthcare Policy.” Health Progress 80 (1999): 41-44, 47.

21. R. Wilson, and T. F. Schindler. "Tradition in Transition: What It Means to be a Catholic Healthcare Facility Today.” Health Progress 71 (1990): 26-31.

22. Martin E. Marty. “Can We Still Hear the Call?” Health Progress 76 (1995): 18-21.

23. Carol S. Weisman, A. J. Khoury, C. Cassirer, V. A. Sharpe, and Laura Morlock. “The Implications of Affiliations between Catholic and Non-Catholic Health Care Organizations for Availability of Reproductive Health Services.” Women’s Health Issues 9 (1999): 121-34.

24. Thomas R. Prince, and R. Ramanan "Operating Performance and Financial Constraints of Catholic Community Hospitals, 1986-1989.” Health Care Management Review 19 (1994): 38-48.

25. Boxiong Tang. "The Impact of Competition on the Financial Performance of Catholic Hospitals.”PhD diss., Saint Louis University, 1995.

26. Kenneth R. White. “Catholic Healthcare: Isomorphism or Differentiation?” PhD diss., Virginia Commonwealth University, 1996.

27. Kenneth R. White, and Yasar A. Ozcan. "Church Ownership and Hospital Efficiency.” Hospital \& Health Services Administration 41 (1996): 297-310.

28. Kenneth R. White, and James W. Begun. "How Does Catholic Hospital Sponsorship Affect Services Provided?” Inquiry 35 (1998/99): 398-407.

29. Kenneth R. White, James W. Begun, and Wenqiang Tian. "Hospital Service Offerings: Does Catholic Ownership Matter?” Health Care Management Review 31 (2006): 99-108.

30. Tiang-Hong Chou, Yasar A. Ozcan, and Kenneth R. White. "Technical and Scale Efficiencies of Catholic Hospitals: Does a System Value of Stewardship Matter?” In Advanced Decision Making Methods Applied to Health Care, edited by E. Tanfani and A. Testi. London: Springer Publishers, 2012, pp. 83-101.

31. Kenneth R. White, Clarke E. Cochran, and Urvashi B. Patel. "Hospital Provision of End-of-Life Services: Who, What, and Where?” Medical Care 40 (2001): 17-25.

32. Clarke E. Cochran, and Kenneth R. White. “Does Catholic Ownership Matter?” Health Progress (2002): 14-16, 50. 
33. Kenneth R. White, Tiang-Hong Chou, and Roberto Dandi. "Catholic Hospital Services for Vulnerable Populations: Are System Values Sufficient Determinants?” Health Care Management Review 35 (2010): 175-186

34. W. Richard Scott. Institutions and Organizations, 3rd ed. Los Angeles: Sage, 2008.

35. W. Richard Scott, and Gerald F. Davis. Organizations and Organizing: Rational, Natural, and Open System Perspectives. Upper Saddle River: Pearson/Prentice-Hall, 2007.

36. P. Selznick. "Foundations of the Theory of Organization.” American Sociological Review 13 (1948): 25-35.

37. W. Richard Scott, and John W. Meyer. Institutional Environments and Organizations: Structural Complexity and Individualism. Thousand Oaks: Sage Publications, 1994.

38. W. Richard Scott. “Goals, Power, and Control.” In Organizations: Rational, Natural, and Open Systems, 3rd ed. Englewood Cliffs: Prentice-Hall, 1998, pp. 76-94.

39. John W. Meyer, and W. Richard Scott. "Centralization and Legitimacy Problems of Local Governments.” In Organizational Environments: Ritual and Rationality, edited by John W. Meyer, and W. Richard Scott. Beverly Hills Sage Publications, 1983, pp. 199-216.

40. Paul J. DiMaggio, and Walter W. Powell. "The Iron Cage Revisited: Institutional Isomorphism and Collective Rationality in Organizational Fields.” American Sociological Review 48 (1983): 147-60.

41. Kenneth R. White, and John R. Griffith. The Well-Managed Healthcare Organization, 7th ed. Chicago: AUPHA Press/Health Administration Press, 2010.

42. John W. Meyer, and B. Rowan. "Institutionalized Organizations: Formal Structure as Myth and Ceremony.” American Journal of Sociology 83 (1977): 340-63.

43. Paul M. Starr. The Social Transformation of American Medicine. New York: Basic Books, 1982.

44. Rosemary Stevens. In Sickness and in Wealth: American Hospitals in the Twentieth Century. New York: Basic Books, 1989.

45. C. DeWitt. “Getting Down to Business.” Hospitals 55 (1981): 76-78.

46. Eric Abrahamson, and Lori Rosenkopf. "Institutional and Competitive Bandwagons: Using Mathematical Modeling as a Tool to Explore Innovation Diffusion.” Academy of Management Review 18 (1993): 487-517.

47. Jeffrey A. Alexander, and Thomas A. D’Aunno. “Transformation of Institutional Environments Perspectives on the Corporatization of U.S. Health Care.” In Innovations in Health Care Delivery: Insights for Organization Theory, edited by Stephen S. Mick. San Francisco: JosseyBass, 1990, pp. 53-85.

48. Ruth A. Mohr. "An Institutional Perspective on Rational Myths and Organizational Change in Health Care.” Medical Care Review 49 (1992): 233-55.

49. Susan D. Roggenkamp, and Kenneth R. White. "Is Hospital Case Management a Rationalized Myth?” Social Science \& Medicine 53 (2001): 1057-66.

50. Mary L. Fennell, and Jeffrey A. Alexander. "Organizational Boundary Spanning in Institutionalized Environments.” Academy of Management Journal 30 (1987): 456-76.

51. Michael J. McCue, Jan P. Clement, and Roice D. Luke. "Strategic Hospital Alliances: Do the Type and Market Structure of Strategic Hospital Alliances Matter?” Medical Care 37 (1999): 1013-22. 
52. Mark C. Suchman. “Managing Legitimacy: Strategic and Institutional Approaches.” Academy of Management Review 20 (1995): 571-610.

53. John W. Meyer, and W. Richard Scott. Organizational Environments: Ritual and Rationality. Beverly Hills: Sage Publications, 1992.

54. Walter Powell, and Paul DiMaggio, eds. The New Institutionalism in Organizational Analysis. Chicago: The University of Chicago Press, 1991.

55. Lynn G. Zucker. “Institutional Theories of Organization.” Annual Review of Sociology 13 (1987): 443-64.

56. Allen J. LeBlanc. "Undercompensated, Unpopular Services in Hospitals: The Case of HIV/AIDS.” PhD diss., Pennsylvania State University, 1991.

57. Anne-Claire Pache, and Felipe Santos. "When Worlds Collide: The Internal Dynamics of Organizational Responses to Conflicting Institutional Demands.” Academy of Management Review 35 (2010): 455-76.

58. Roice D. Luke, James W. Begun, and Stephen S. Walston. "Strategy in Health Care Organizations and Markets.” In Health Care Management: Organizational Design and Behavior, edited by Stephen Shortell and Arnold Kaluzny. New York: Delmar Publishers Inc., 2000.

59. Allen J. LeBlanc, and Robert E. Hurley. “Adoption of HIV-Related Services Among Urban US Hospitals: 1988 and 1991.” Medical Care 33 (1995): 881-91.

60. Clarke E. Cochran. "Institutional Identity; Sacramental Potential: Catholic Healthcare at Century’s End.” Christian Bioethics 5 (1999): 26-43.

61. Richard A. McCormick. Corrective Vision: Explorations in Moral Theology. Kansas City: Sheed \& Ward, 1994.

62. Richard A. McCormick. “The Catholic Hospital Today: Mission Impossible?” Origins 24 (1995): 648-53.

63. M. Evans. “Another Diocese Opts Out.” Modern Healthcare 37 (2007): 16.

64. Francis Sullivan. "Ensuring the Sustainability and Effectiveness of Catholic Health Care.” Third International Congress: Aggiornamento of the Catholic Healthcare Ministry, Vatican City, 4 May 2007.

65. American Hospital Association Annual Survey. 2010. Available online: http://www.chausa.org/ Pages/Newsroom/Fast_Facts/ (accessed on 28 October 2012).

66. Catholic Health Care in the United States. 2012. Available online: http://www.chausa.org/Pages/ Newsroom/Fast_Facts/ (accessed on 28 October 2012).

67. A. Selvam. “Ky. Deal Forms with Just Two.” Modern Healthcare 42 (2012): 10.

68. Gareth R. Jones. Organizational Theory: Text and Cases. Reading: Addison-Wesley Publishing Company, 1995.

69. Sanjay B. Saxena, and Terry G. Williams. "The Case for Creative Partnering.” Health Progress 93 (2012): 36-40.

(C) 2012 by the author; licensee MDPI, Basel, Switzerland. This article is an open access article distributed under the terms and conditions of the Creative Commons Attribution license (http://creativecommons.org/licenses/by/3.0/). 